\title{
Between neo-Ottomanism and Ottomania: navigating state-led and popular cultural representations of the past
}

\author{
Murat Ergin and Yağmur Karakaya
}

\begin{abstract}
In contemporary Turkey, a growing interest in Ottoman history represents a change in both the official state discourse and popular culture. This nostalgia appropriates, reinterprets, decontextualizes, and juxtaposes formerly distinct symbols, ideas, objects, and histories in unprecedented ways. In this paper, we distinguish between state-led neo-Ottomanism and popular cultural Ottomania, focusing on the ways in which people in Turkey are interpellated by these two different yet interrelated discourses, depending on their social positions. As the boundary between highbrow and popular culture erodes, popular cultural representations come to reinterpret and rehabilitate the Ottoman past while also inventing new insecurities centering on historical "truth." Utilizing in-depth interviews, we show that individuals juxtapose the popular television series Mubteşem Yüzyıl (The Magnificent Century) with what they deem "proper" history, in the process rendering popular culture a "false" version. We also identify four particular interpretive clusters among the consumers of Ottomania: for some, the Ottoman Empire was the epitome of tolerance, where different groups lived peacefully; for others, the imperial past represents Turkish and/or Islamic identities; and finally, critics see the empire as a burden on contemporary Turkey.
\end{abstract}

Keywords: Ottomania; neo-Ottomanism; popular culture; modernity; history; The Magnificent Century

Murat Ergin, Koç University, Department of Sociology, Rumeli Feneri Yolu 34450, Sarıyer, İstanbul, Turkey, muergin@ku.edu.tr.

Yağmur Karakaya, University of Minnesota, Department of Sociology, 267 19th Ave. S \#909, Minneapolis, MN 55455, USA, karak014@umn.edu.

Authors' Note: The authors are listed alphabetically, as each is an equal co-author. We would like to thank the editors and anonymous reviewers of New Perspectives on Turkey for their helpful comments and criticisms. 


\section{Introduction}

Contemporary Turkey is saturated with nostalgia for its Ottoman past. Millions tune in to television series where palace intrigues play out between sultans and women of the harem. Five centuries after her time, Hürrem-the wife of Süleyman the Magnificent ( $r .1520-1566)$, commonly known as Roxelana in the West-shapes fashion statements thanks to the popular television series Mubteşem Yüzyıl (The Magnificent Century), with women from different sections of society wearing replicas of her jewelry. In photography studios, people have their pictures taken in Ottoman-period costumes, enjoying and displaying memorialized versions of themselves as sultans and sultanas. Restaurants offer menus peppered with the word "Ottoman." Bookstores abound with popular books and magazines promising readers the story of the "real" Ottomans. Ottoman Turkish courses and the collecting of antiques are growing ever more popular. Lavish shopping malls feature shops selling $\mathrm{T}$-shirts decorated with Ottoman tuğras, the sultans' calligraphic seals. Five-star hotels and health clubs have discovered a long neglected and formerly disdained Ottoman institution and adapted it to modern consumption: the hamam, or traditional Turkish bath. Along with these popular forms of consuming the Ottoman past, the state is also promoting its own vision of the Ottoman past through such events as the celebration of the conquest of İstanbul in 1453, commemorating this event through a panoramic museum, as well as by disseminating a vision of a multicultural, just, welcoming, and peaceful Ottoman past through public speeches, textbooks, and publications.

This paper investigates the ways in which the public in Turkey makes sense of neo-Ottomanism and Ottomania as two interrelated processes of history and memory. We first discuss neo-Ottomanism as a political project aimed at reviving the Ottoman past in a variety of domains, including the urban fabric, anniversary celebrations, and foreign policy. The remainder of the paper discusses Ottomania, this project's counterpart in popular culture. As a field where struggles over meaning and representation take place, popular culture reflects how the rising interest in the Ottoman past corresponds to historical shifts in the meaning of "modernity" and "tradition." As a commercialized popular culture invades formerly highbrow domains, pleasure comes to the defense of a highly stylized and dramatized past. Thus, contemporary attempts to reinterpret the past go diametrically against the historical vision of 'Turkey's republican modernization. The result is a shift away from the insecurities of high cultural modernization, which in turn paves the way for efforts to rehabilitate a nebulous Ottoman and Islamic tradition in multiple ways. However, the popularization and commercialization of history leads to new anxieties regarding historical authenticity. The final part of the paper examines 
interview data to discuss how respondents confront these issues through four different interpretive strategies.

The rising interest in and redefinition of Turkey's Ottoman past represents a process of reevaluating Turkey's historical heritage. ${ }^{1}$ Over the past two decades, scholars have examined the "memorial turn" in the Turkish context, and have indicated that this rising interest in the past might be a symptom of nostalgia, ${ }^{2}$ of the destruction of communal life, and of the absence of social memory in everyday life. ${ }^{3}$ While "memories create identities and help members of the nation come to terms with the past and with national traumas, by either highlighting or concealing them,"4 in many ways public emotions get transmitted and constituted through life stories. ${ }^{5}$ In a similar vein, Meltem Ahıska interrogates the destruction of Ottoman archives as another interface between history and memory, as well as between history and truth. ${ }^{6}$

Articulations of the Ottoman past in contemporary Turkey belong to a wide array of remembering endeavors. The interest in the Ottoman past is constitutive of a social system where "being Muslim [is] a cultural and ethical identity associated with being Turkish, but no longer with Kemalist nationalism." It emerges in a context where official Kemalism is no longer able to provide for the needs of the new urbanites, who seem to require a different kind of moral map in the post-1980s period. Aslı Iğsız, in looking at the museum for the Greco-Turkish population exchange, focuses on the multiculturalist aspect of the appropriation of the Ottoman past, defining it as "a discourse on the past intended to legitimize contemporary neoliberal and cultural policies by drawing on anachronistic reinterpretations and the glorification of the Ottoman past in Turkey." ${ }^{8}$ Potuoğlu-Cook sees nostalgia for the Ottoman past as a discursive and material cross-fertilization across both Islamist and secular circles, inasmuch as these draw from the same discursive pool where the domains of symbolic and political economy overlap in multiple and contradictory ways. ${ }^{9}$

1 Dan Bilefsky, "Frustrated with West, Turks Revel in Empire Lost," The New York Times, December 5, 2009.

2 Esra Özyürek, The Politics of Public Memory in Turkey (Syracuse: Syracuse University Press, 2007).

3 Meltem Ahıska and Biray Kolluoğlu Kırlı, "Editors' Introduction," New Perspectives on Turkey 34 (2006): 5-8.

4 Özyürek, The Politics of Public Memory in Turkey, 7.

5 Nükhet Sirman, "Constituting Public Emotions through Memory: Interviewing Witnesses," New Perspectives in Turkey 34 (2006): 31-46.

6 Meltem Ahıska, "Occidentalism and Registers of Truth: The Politics of Archives in Turkey," New Perspectives on Turkey 34 (2006): 9-28.

7 Jenny White, Muslim Nationalism and the New Turks (Princeton, NJ: Princeton University Press, 2014), 126.

8 Aslı lğsız, "Palimpsests of Multiculturalism and Museumization of Culture: Greco-Turkish Population Exchange Museum as an İstanbul 2010 European Capital of Culture Project," Comparative Studies of South Asia, Africa and the Middle East 35, no. 2 (2015): 324-345.

9 Öykü Potuoğlu-Cook, "Beyond the Glitter: Belly Dance and Neoliberal Gentrification in İstanbul," Cultural Anthropology 21, no. 4 (2006): 633-660. 
The increasing interest in the Ottoman past can be analyzed through two separate, yet interrelated, analytical categories: neo-Ottomanism, and Ottomania. The former refers to the current policies of the ruling Justice and Development Party (Adalet ve Kalkinma Partisi, AKP) geared toward promoting nostalgia via an emphasis on the Ottomans multiculturalism, cosmopolitanism, and tolerance. As compared to this project's nationalistic, solemn, and masculine inclinations, Ottomania embraces popular culture with an emphasis on consumption of a wide spectrum of products, from bath packages to television series. These two forms of nostalgia are in a continuous dialogue and friction. Therefore, we argue that current representations of the Ottoman past are both the product of a deliberate state project and a decentralized collection of consumption practices.

Based on twenty-five in-depth interviews focusing on popular cultural representations of the Ottoman Empire and what the Ottoman past in general signifies for informants, we examine how the interviewees are interpellated by neo-Ottomanism and Ottomania. Our findings indicate that one group views Ottoman history as the epitome of tolerance. The second and third interpretations see in the Ottoman past, respectively, a Turkish and a Muslim empire. Finally, for some, popular culture glorifies nothing more than a past filled with concealed atrocities. Regardless of such differences of opinion, most respondents claim that popular culture waters down "historical truth" and disseminates a "false history." Our aim in this paper is to flesh out the discourses surrounding history and examine how phrases like "proper history," "false history," and "true history" shift across different subjectivities. As authors, we do not adhere to or propose any model as to what "proper" history should look like, but we do accept Stuart Hall's invitation to study popular culture as a domain where struggles over the meaning of politically enforced cultural scripts take place, ${ }^{10}$ and we examine what the negotiation between neo-Ottomanism and Ottomania looks like within the framework of articulations of different shades of history. As Alejandro Baer says, "[f]ormerly clear-cut distinctions between popular and recognized history, education and entertainment, fictional construction and historical documentation, are less and less certain."11 Thus, this debate should go beyond the dichotomy of truth versus falsehood so as to instead recognize and shift the attention to the growing presence of these hybrid products of popular and "proper" history, as well as how they are articulated and perceived in public debate.

10 Stuart Hall, "Encoding/Decoding," in Culture, Media, Language: Working Papers in Cultural Studies, 1972-79, ed. Stuart Hall, Dorothy Hobson, Andrew Lowe, and Paul Willis (London: Routledge, 2005 [1980]): 117-127.

11 Alejandro Baer, "Consuming History and Memory through Mass Media Products," European Journal of Cultural Studies 4, no. 4 (2001): 491-501. 


\section{Neo-Ottomanism and Ottomania}

The establishment of the Republic of Turkey in 1923 witnessed a process of nation-building revolving around a pre-Islamic Turcocentric worldview. ${ }^{12}$ This vision relied on affective mass settings of collective effervescence, such as the tenth-anniversary celebration of the establishment of the republic, ${ }^{13}$ to create identification with a mythic central Asian past, emphasizing a pre-Islamic Turkish folk culture where an untouched, unimperial, and independent Turkishness existed. The resulting narrative relegated Turkey's Ottoman past to a forgettable episode of decline. ${ }^{14}$ Placed against this background of modernization, neo-Ottomanism and Ottomania constitute frontal challenges to the republic's foundational narrative, rewriting the historical script that rejected Turkey's Islamic and imperial past for a secular and Western society.

Neo-Ottomanism is a nostalgic project led in contemporary Turkey by the AKP government. ${ }^{15}$ It shapes foreign policy, multicultural cosmopolitan identity politics at home, and the discourse of urban transformation. Unlike the early republican elite, the new conservative Muslim elite derive their historical inspiration predominantly from the Ottoman Empire, which they see and portray as a multicultural, pious, just, and harmonious cradle of civilization. Esra Özyürek traces the beginnings of this phenomenon to the 1990s: looking at the 75 th anniversary celebrations of the republic, she writes, "the promoters of neo-Ottomanism had a rather flattened sense of the seven-hundred-yearlong rule of the Ottomans and saw the empire as a proof of the superior achievements of a 'Turkish' state that accepted Islam as its official religion." ${ }^{16}$ Similarly, Jenny White argues that nostalgia for an ethical past emerged in the context of a socioeconomic environment where the Ottoman Empire "[had] been dusted off to provide models for everything from tolerant multiculturalism to veiling styles and architectural models for summer resorts." ${ }^{17}$

12 See Murat Ergin, Is the Turk a White Man? Race and Modernity in the Making of Turkish Identity (Leiden: Brill, 2016); Meral Uğur Çınar, Collective Memory and National Membership: Identity and Citizenship Models in Turkey and Austria (London: Palgrave Macmillan, 2015); Alev Çınar, Modernity, Islam, and Secularism in Turkey: Bodies, Places, and Time (Minneapolis: University of Minnesota Press, 2005).

13 See Esra Özyürek's account of the mythologized tenth-anniversary celebration in Esra Özyürek, Nostalgia for the Modern: State Secularism and Everyday Politics in Turkey (Durham: Duke University Press, 2006).

14 See, e.g., Illker Aytürk, "Turkish Linguists against the West: The Origins of Linguistic Nationalism in Atatürk's Turkey," Middle Eastern Studies 40, no. 6 (2004): 1-25; Büşra Ersanlı, "The Ottoman Empire in the Historiography of the Kemalist Era: A Theory of Fatal Decline," in The Ottomans and the Balkans: A Discussion of Historiography, ed. Fikret Adanır and Suraiya Faroqhi (Leiden: Brill, 2002): 115-154; and Donald Quataert, The Ottoman Empire, 1700-1922 (Cambridge and New York: Cambridge University Press, 2008).

15 See White, Muslim Nationalism and the New Turks.

16 Özyürek, The Politics of Public Memory in Turkey, 121.

17 White, Muslim Nationalism and the New Turks, 127. 
In this context, the Welfare Party (Refab Partisi, RP) and Virtue Party (Fazilet Partisi, FP), which marked the rise of Islamic politics in Turkey in the 1990s, championed neo-Ottoman ideas like Ottomanesque religious federalism (the millet system) and religiously inspired charity programs as an alternative to the welfare state. The AKP, established by a splinter group of the RP and FP, came to power in 2002 and further extended this neo-Ottomanist agenda.

As a central narrative of the ruling AKP, neo-Ottomanism has implications for Turkey's domestic and foreign politics. ${ }^{18}$ Illustrated by the foundational text Stratejik Derinlik (Strategic Depth), a book penned by the former Minister of Foreign Affairs and later Prime Minister Ahmet Davutoğlu, the foreign policy face of neo-Ottomanism envisions a pax Ottomanica in the hinterland of the Ottoman Empire, with the aim being to establish ties with countries in the Middle East and the Balkans at the expense of Turkey's traditional orientation towards the West. ${ }^{19}$ Davutoğlu claims that reintegrating with the Middle East is Turkey's historical and geographical destiny. ${ }^{20}$

In domestic politics, the political establishment increasingly emphasizes the Ottoman past, as evidenced by zealous celebrations of Ottoman-related anniversaries like the conquest of İstanbul; the revitalization of Ottoman themes in government-controlled venues, such as textbooks and banknotes; and ever intensifying attempts to shape the urban fabric according to a nostalgic view of the Ottoman past. The last of these range from Ottoman-themed museums, such as the Panorama 1453 History Museum, to colossal mosques meant to imitate the grandeur of Ottoman sultans, such as the controversial mosque constructed on the hills of Çamlica in İstanbul. One of the specific triggers for the anti-government demonstrations held at İstanbul's Gezi Park in 2013 was an attempt to raze this public park so as to construct a replica of an Ottoman barracks that would serve as a shopping mall. This can serve as an apt symbol for how neo-Ottomanism is immersed in explicit political efforts to shape the country in the midst of a neoliberal economic transformation. The intensity of the Gezi protests, however, indicates that this top-down imposition of Ottoman nostalgia is challenged by different groups.

Neo-Ottomanism in urban life, especially the ways in which it has served as an impetus to transform neighborhoods and embark on projects of museumization, has been scrutinized by scholars from a number of different angles. ${ }^{21}$

18 Nora Fisher Onar, "Constructing Turkey Inc.: The Discursive Anatomy of a Domestic and Foreign Policy Agenda," Journal of Contemporary European Studies 19, no. 4 (2011): 463-473.

19 See Alexander Murinson, "The Strategic Depth Doctrine of Turkish Foreign Policy," Middle Eastern Studies 42, no. 6 (2006): 945-964.

20 Ahmet Davutoğlu, Stratejik Derinlik: Türkiye'nin Uluslararası Konumu (İstanbul: Küre Yayınları, 2011).

21 See Marcy Brink-Danan, "Dangerous Cosmopolitanism: Erasing Difference in İstanbul," Anthropological Quarterly 84, no. 2 (2011): 439-473; Marcy Brink-Danan, Jewish Life in Twenty-First-Century 
Ayfer Bartu examines the Beyoğlu/Pera district in İstanbul both in the 1980s and after the municipal elections of 1994, when the RP's candidate, Recep Tayyip Erdoğan-who later founded the AKP and is currently serving as Turkey's president-was elected as the mayor of İstanbul. ${ }^{22}$ During this period, the image of İstanbul was orientalized via phrases like "the East in the West, and the West in the East" and a "gateway to the Orient."23 As opposed to the idea of Beyoğlu/Pera being the representative of European İstanbul, RP representatives used their rule "as a crucial opportunity to demonstrate the workings of the 'Ottoman model of government,' which they defined as the coexistence of different lifestyles." 24 Similarly, a study on Kuzguncuk shows how this neighborhood, like others in İstanbul, was reimagined with reference to a multicultural Ottoman past. ${ }^{25}$ A nostalgic popular memory for the neighborhoods of İstanbul has developed, one that glosses over conflict through a myth of harmony and conviviality. What is more, neo-Ottoman urban endeavors also dislocate the urban poor and create new mechanisms of gentrification in İstanbul's historic neighborhoods, which thereby are rediscovered by the upper classes. ${ }^{26}$

In line with such neo-Ottomanist urban interventions, the 2000s witnessed the rise of an official discourse that endorsed diversity in Turkey and embellished an image of coexistence, harmony, and tolerance "without mention of aversion or power issues." ${ }^{27}$ One example is the Greco-Turkish Population Exchange Museum, which presents an artificial coexistence and renders multiculturalism as something novel, "whereby visibility and display are conflated with recognition, without necessarily opening spaces to contest

Turkey: The Other Side of Tolerance (Bloomington: Indiana University Press, 2011); Amy Mills, "The Ottoman Legacy: Urban Geographies, National Imaginaries, and Global Discourses of Tolerance," Comparative Studies of South Asia, Africa and the Middle East 31, no. 1 (2011): 183-195; Amy Mills, Streets of Memory: Landscape, Tolerance, and National Identity in Istanbul (Athens: University of Georgia Press, 2010); Karen Barkey, "Rethinking Ottoman Management of Diversity: What Can We Learn for Modern Turkey?" in Democracy, Islam and Secularism in Turkey, ed. Ahmet Kuru and Alfred Stepan (New York: Columbia University Press, 2010): 12-31; and lğsız, "Palimpsests of Multiculturalism and Museumization."

22 Ayfer Bartu, "Rethinking Heritage Politics in a Global Context: A View from İstanbul," in Hybrid Urbanism: On the Identity Discourse and the Built Environment, ed. Nezar AlSayyad (Westport, CN: Praeger Publishers, 2001): 131-155.

23 Bartu, "Rethinking Heritage Politics in a Global Context," 136.

24 Ibid., 146.

25 See Mills, Streets of Memory.

26 Ayfer Bartu Candan and Biray Kolluoğlu, "Emerging Spaces of Neoliberalism: A Gated Town and a Public Housing Project in İstanbul," New Perspectives on Turkey 39 (October 2008): 5-46; Tuna Kuyucu and Özlem Ünsal, "'Urban Transformation' as State-Led Property Transfer: An Analysis of Two Cases of Urban Renewal in İstanbul," Urban Studies 47, no. 7 (2010): 1479-1499; Dikmen Bezmez, "The Politics of Urban Regeneration: The Case of the Fener and Balat Initiative," New Perspectives on Turkey 37 (October 2007): 59-86.

27 Iğsız, "Palimpsests of Multiculturalism and Museumization," 327. 
disparities, injustice, or power." ${ }^{28}$ Brink-Danan similarly problematizes the discourse of cosmopolitanism by looking at how the Jewish community in İstanbul faced occasional bouts of public and private discrimination throughout Ottoman and republican history, thereby being compelled to watch their public behavior and "tame" their differences. ${ }^{29}$ At the same time, however, in the context of cherishing an imaginary Ottoman cosmopolitanism, the Jewish minority in İstanbul also became revered as ancestral remnants of cosmopolitanism lost. ${ }^{30}$ Karen Barkey argues that "politicians are reaching back into history to claim a history of toleration and coexistence without fully understanding the context of its emergence, deployment, and tragic undoing." ${ }^{31}$ She finds it disconcerting how this view chops up and freezes history, "claiming ancestry with Ottoman toleration while denying any relation to the final annihilation of diversity in the transition from empire to nation., ${ }^{32}$

Ottomania, while in dialogue with neo-Ottomanism, pertains to the cultural aspects of the fascination with the Ottoman past. To this end, in this article we examine the manifestation of Ottomania in popular culture through a decentralized but integrated network of images, symbols, and items ready for consumption. We focus specifically on the television drama Mubteşem Yüzyıl (The Magnificent Century) as one of the most widely debated examples of Ottomania in popular culture. Moreover, through the interview data, we show how Ottomania and neo-Ottomanism speak to each other in such a way as to produce new articulations indicative of anxieties relating to historical "truth" and Turkish and Islamic identities.

Our findings come from in-depth interviews with twenty-five individuals. In order to recruit interviewees, we specified the design parameters-cities to be included, gender, socioeconomic background, and age-and asked the recruiters of a research company to identify suitable individuals. Following the recruitment process, the research company's involvement ended and the authors became the sole points of contact. During recruitment, it emerged that certain demographic groups, such as older people and persons with lower levels of educational attainment, were less likely to accept participating. This resulted in a sample that relatively overrepresents younger individuals who are either college students or college graduates. We presented the participants with small gifts, such as tea glasses and chocolate, which cost ten to fifteen Turkish liras (roughly equivalent to four to five US dollars) per person. The resulting sample included fifteen participants from İstanbul and five from İzmir and Kayseri each.

28 Ibid., 337.

29 Brink-Danan, Jewish Life in Twenty-First-Century Turkey.

30 Ibid., 444.

31 Barkey, "Rethinking Ottoman Management of Diversity," 13.

32 Ibid. 
Our goal in sample selection was to identify different discursive clusters rather than to achieve demographic representativeness. It was with this idea in mind that we selected three cities: İstanbul contains a diverse population; İzmir was selected to represent the coastal secular/liberal position that is frequently in opposition to the current government's cultural policies; and Kayseri serves as a good representative of the so-called "Anatolian tigers," the conservative and business-oriented population emerging in the country's heartland, such as in Konya, Bursa, and Denizlii. ${ }^{33}$ The sample included eleven women and fourteen men. Eight of the respondents were college graduates and eleven were high school graduates (of whom four were college students at the time of the interview). Nine of the respondents were in the eighteen-to-thirty age group. For a full list of respondents with their corresponding socioeconomic data, see Table 1.

The majority of the interviews lasted between thirty minutes and two hours, and all were recorded and transcribed. Interviews were conducted solely by one of the authors, and the majority took place at the respondent's home or workplace, except for five that were conducted in public places. The interviews were semi-structured and contained seven sections. Following introductory questions concerning demographic and housing information, subsequent sections included questions about the respondent's perceptions of and activities relating to culture and leisure, literature, Ottoman history, history education, consumption items related to Ottoman history, and politics and religion. Each section began with broader questions (e.g., what types of television programs the respondent likes) and ended with more targeted questions (e.g., what the respondent thinks about Ottoman-themed television dramas). In this article, the majority of the findings come from two clusters of questions: the respondents' perceptions of Ottoman history and its consumption, and a more focused discussion on representations of the Ottoman past on television, particularly in the program The Magnificent Century.

\section{Nostalgia for the Ottoman Empire in popular culture: The Magnificent Century}

The Magnificent Century (Turkish, Mubteşem Yüzyll) is a prime-time soap opera based on the lives of the Ottoman sultan Süleyman the Magnificent (r. 1520-1566) and his wife Hürrem (also known as Roxelana in the West), a Ukrainian slave who became one of the most powerful female figures in Ottoman history. Süleyman's reign is popularly seen as the zenith of the

33 Kemal Kirişçi and Neslihan Kaptanoğlu, "The Politics of Trade and Turkish Foreign Policy," Middle Eastern Studies 47, no. 5 (2011): 705-724. 
Table 1. Demographic information of respondents

\begin{tabular}{|c|c|c|c|c|c|}
\hline Respondent & Gender & Education & Age & Occupation & City \\
\hline 1 & Female & College & 21 & Student & İstanbul \\
\hline 2 & Female & College & 24 & Student & İstanbul \\
\hline 3 & Female & High school & 49 & Housewife & İstanbul \\
\hline 4 & Female & College & 32 & Student & İstanbul \\
\hline 5 & Female & High school & 40 & Housewife & İstanbul \\
\hline 6 & Male & High school & 35 & Shopkeeper & İstanbul \\
\hline 7 & Male & Primary school & 37 & Café owner & İstanbul \\
\hline 8 & Female & High school & 30 & Shopkeeper & İstanbul \\
\hline 9 & Male & College & 33 & Marketing expert & İstanbul \\
\hline 10 & Male & College & 25 & Student & İstanbul \\
\hline 11 & Female & Middle school & 45 & Housewife & İstanbul \\
\hline 12 & Male & High school & 28 & Shopkeeper & İstanbul \\
\hline 13 & Male & College & 31 & Café owner & İstanbul \\
\hline 14 & Male & College & 44 & Self-employed & İstanbul \\
\hline 15 & Male & High school & 18 & Student & İstanbul \\
\hline 16 & Male & High school & 31 & Construction worker & İzmir \\
\hline 17 & Female & College & 32 & Chemist & $\dot{I}_{z m i r}$ \\
\hline 18 & Female & College & 26 & Teacher & İzmir \\
\hline 19 & Male & Middle school & 25 & Musician & İzmir \\
\hline 20 & Male & College & 29 & Accountant & İzmir \\
\hline 21 & Female & High school & 40 & Housewife & Kayseri \\
\hline 22 & Female & College & 33 & Housewife & Kayseri \\
\hline 23 & Male & High school & 33 & Civil servant & Kayseri \\
\hline 24 & Male & Middle school & 35 & Shopkeeper & Kayseri \\
\hline 25 & Male & College & 45 & Manager in private sector & Kayseri \\
\hline
\end{tabular}

Ottoman Empire. The Magnificent Century focuses on his love life with Hürrem and on harem intrigues. The series caused a great uproar and triggered debates concerning historical accuracy-what Öncü calls "public chatter"with the debates centered on personalities and events and proliferating across different publics without achieving any definitive resolution. ${ }^{34}$ The public was mesmerized by such questions as whether or not it was appropriate to depict a sultan's personal life in such detail and whether or not concubines actually wore such low-cut dresses. The show reached a large audience both in Turkey and abroad. However, the current president, Recep Tayyip Erdoğan, among others, condemned it for falsely depicting the Ottoman "forefathers" spending their lives involved in harem intrigues rather than fighting on horseback. Several high-ranking AKP members asked the producers, the Taylan Brothers, to

34 Ayşe Öncü, "Representing and Consuming 'The East' in Cultural Markets," New Perspectives on Turkey 45 (2011), 53. 
discontinue the show. Although they refused to follow suit, the Taylan Brothers faced fines and, according to a 2013 interview in The New Yorker, implemented self-censorship, particularly by a conscious inclusion of more battle scenes. ${ }^{35}$ Both the then script writer, Meral Okay, and the Taylan Brothers emphasized that they did not align themselves with any politics or ideology in relation to the Ottoman past, and that what they were doing was creating characters inspired by history and thus ultimately creating historical fiction. Okay also argued that she faced extensive criticism because of her gender, stating that a man in her position would probably not have been criticized as much or as heavily. ${ }^{36}$

One of the main themes in the public debates surrounding the show related to its historical inaccuracies. Within this context, the popular history magazine NTV Tarib dedicated an entire issue to historical accuracy, providing extended information on Ottoman society in the sixteenth century. ${ }^{37}$ While the overall tone of the issue appears to be critical of the show's historical inaccuracies, it also had positive things to say regarding how such popular interest raised awareness of history education. These debates surrounding historical accuracy are reminiscent of the new national and historical vision seen in neo-Ottomanism, which is also in tension with other visions of history.

Public debates provide us with a platform to examine the dialogue and tension between neo-Ottomanism and Ottomania. In particular, they highlight the popular appeal of Ottomania and the efforts to tame it by neo-Ottoman concerns, especially in terms of displaying a disciplined and ascetic Ottoman society that keeps sexuality and desires under control. Moreover, The Magnificent Century also shows how the state's control over popular culture has changed. Beginning in the 1930s, Turkey's state elite channeled their anxieties about Westernization toward popular culture, resulting in a suspicious and controlling attitude toward representations of the popular. The modernizers' attitude was one of cultural tutelage that entailed widespread intervention in music, film, radio, and the arts. Such questionable practices as banning Ottoman court music from state radio in order to promote Western music rather clearly illustrate the perceived links between popular culture and modernity. ${ }^{38}$ Starting in the commercialized 1990s, as pointed out by Öncü, "the capacity of the Turkish state to monopolize culture through state

35 Elif Batuman, "Ottomania: A hit TV show reimagines Turkey's imperial past," The New Yorker, February 17, 2014. http://www.newyorker.com/magazine/2014/02/17/ottomania.

36 Ceyda Aşar, "Muhteşem Üçlü," Milliyet Sanat 624, March 2011, 61-63.

37 Necdet Sakaoğlu and Ayşen Gür, "Muhteşem Yüzyılın Anatomisi: Sultan Süleyman Dönemi Dünya Sistemi," NTV Tarih 25 (February 2011): 26-39.

38 Murat Ergin, "On Humans, Fish, and Mermaids: The Republican Taxonomy of Tastes and Arabesk," New Perspectives on Turkey 33 (2005): 63-92. 
institutions-the school, the university, the army-has been progressively undermined." 39 State discourses also gradually became intertwined with the consumption of history. In this context, Ottomania becomes a venue for reevaluating and rehabilitating a tradition that was rejected by republican modernization, and it becomes a domain where contemporary neo-Ottomanism can be either reproduced or challenged. Pursuing these continuities and ruptures, we view popular culture in Turkey as a contentious domain indicative of struggles and debates around different views of modernization and history.

The dismantling of the boundary between state-sponsored highbrow culture and popular cultural forms is not unique to Turkey. Ottoman-themed Turkish television dramas also garner immense popularity in Middle Eastern countries because they offer an "accessible modernity," which Kraidy and Al-Ghazzi identify as a form of local modernity that is not wholly adopted from the West and to which the average viewer can easily relate. ${ }^{40}$ In contemporary Turkey, such representations of the Ottoman past raise questions about the role of tradition and insecurities about what "proper" history should look like. In both contexts, history becomes a concern for consumption practices. Classic works in the sociology of culture see cultural exclusiveness as an extension of class hierarchies. ${ }^{41}$ However, a growing body of research indicates the rise of omnivorous groups who are not snobs in terms of their cultural consumption. ${ }^{42}$ Research suggests that members of upper strata appreciate and consume popular culture, possibly even in greater depth and breadth than their less privileged counterparts. Likewise, recent research in Turkey indicates the existence of a substantial group of omnivorous cultural consumers and the shifting of boundaries between highbrow and lowbrow cultures. ${ }^{43}$ Although this growing omnivorousness signals the end of a simple correspondence between social and cultural hierarchies, by no means does it mark the end of cultural judgment. ${ }^{44}$

The rise of Ottomania in popular culture corresponds to two specific historical shifts: first, an erosion of cultural boundaries between the highbrow

39 Öncü, "Representing and Consuming," 54.

40 Marwan M. Kraidy and Omar Al-Ghazzi, "Neo-Ottoman Cool: Turkish Popular Culture in the Arab Public Sphere," Popular Communication 11, no. 1 (2013): 17-29.

41 Pierre Bourdieu, Distinction: A Social Critique of the Judgment of Taste, trans. Richard Nice (Cambridge, MA: Harvard University Press, 1984).

42 See Richard A Peterson and Albert Simkus, "How Musical Tastes Mark Occupational Status Groups," in Cultivating Differences: Symbolic Boundaries and the Making of Inequality, ed. Michèle Lamont and Marcel Fournier (Chicago: University of Chicago Press, 1992): 152-168 and Richard A Peterson and Roger M. Kern, "Changing Highbrow Taste: From Snob to Omnivore," American Sociological Review 61, no. 5 (1996): 900-907.

43 Bruce H. Rankin, Murat Ergin, and Fatoş Gökşen, "A Cultural Map of Turkey," Cultural Sociology 8, no. 2 (2014): 159-179.

44 See Peterson and Kern, "Changing Highbrow Taste." 
and the popular; and second, a shift away from the insecurities of a $\underset{m}{z}$ state-sponsored cultural modernity and consequent efforts to rehabilitate an Ottoman and Islamic tradition. While this leads to the popularization and commercialization of history, it also results in new anxieties, this time concerning the authenticity of historical identities.

\section{Pleasure and the popular}

Cultural studies has viewed popular culture as a domain wherein struggles over meaning and representation occur. ${ }^{45}$ Far from being passive consumers, the audiences of popular culture make meaning through a process of struggle and negotiation. In contemporary Turkey, the depiction of Ottoman history on popular television shows is one of the major domains where these representational struggles take place. The commercialization of culture and the erosion of the boundary between state-supported high culture and popular culture placed Ottomania in a reshaped cultural field, with the intense debates about modernization being supplanted by concerns over the reinterpretation of history. Now, the tensions began to emerge between a pleasure-oriented and commercialized popular culture on the one hand and, on the other hand, diverse conceptualizations of what "proper" history might be. These conceptions, united in their criticism of "false" history, range from an emergent traditional interventionism-such as the calls by AKP officials to prohibit depicting the Ottoman past in an irreverent manner-to a reevaluation of the Ottoman past more critically and less nationalistically.

Simon Frith distinguishes three discourses that provide people with tools to make cultural judgments: the art discourse strives to transcend time, space, and the everyday; the folk discourse integrates individuals into a space or community; and the pop discourse provides "routinized pleasures" and

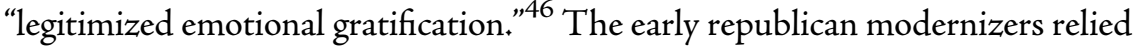
predominantly on the art and folk discourses. Accordingly, art was presented as a means to reach greater truths. When in the 1930s, for example, the government experimented with broadcasting Western music and banning classical Ottoman court music on the radio, the goal was to import the higher artistic truths of the West at the expense of popular demands. ${ }^{47}$ The folk discourse complemented this search by situating it within the context

45 See, e.g., John Fiske and John Hartley, Reading Television (London and New York: Routledge, 2003); Hall, "Encoding/Decoding"; and Raymond Williams, Television: Technology and Cultural Form (London and New York: Routledge, 2003).

46 Simon Frith, "The Good, the Bad, and the Indifferent: Defending Popular Culture from the Populists," Diacritics 21, no. 4 (1991): 106-107.

47 See Ergin, "On Humans, Fish, and Mermaids." 
of local essences. Thus, the art discourse, as a gesture of freedom from tradition, was mapped onto the goals of modernization, whereas the folk discourse ensured that the pursuit of modernity did not veer off into rootless modernity. In conjunction with this, the popular discourse, with its emphasis on pleasure, was relegated to the margins. The economic and cultural transformations occurring since the 1980s have turned pleasure into an accepted defense of the popular. For example, against criticisms that The Magnificent Century depicts a false history, advocates of the show have replied that this soap opera existed solely to provide entertainment.

The 1990s witnessed the dismantling of state-sponsored high cultural judgments. The supporting discourses of art and folk were overwhelmed by the onslaught of a pleasure-seeking popular culture. The gap between popular and official views narrowed when pleasure-oriented evaluations began to be tolerated and even embraced by the state and by intellectuals. In the 1990s, to give one example, as arabesk ${ }^{48}$ stars began to appear on state television and give concerts to the jet set, and as the boundaries between arabesk and Western-style pop music began to erode, the decade-long debates around whether arabesk was modern or degenerate started to make less and less sense. Ottomania proceeds along the same lines, signaling a new period in which the popular declares its independence from the state's agenda of modernization and truth in art, yet nevertheless still remains in dialogue with the state sponsored neo-Ottomanism. As a novel approach to the insecurities about modernization, Ottomania represents an effort to reinterpret and recreate the "tradition" in multiple ways. At the same time, however, taking a stance on history is quite different from doing the same for taste in music insofar as it is intrinsically linked to political and religious identities as well as to nationalistic concerns as to what Turkishness means.

Almost all the respondents in our sample believed that popular representations of Ottoman history amount to a degeneration of the past. The interviewees fall into two camps. The first group clings to the old paradigm and reports refusing to consume products that they believe produce false history. For them, concerns about truth override the pleasures of the popular. Responding to our question of whether he approves of The Magnificent Century, Murat (Respondent 7), a coffeehouse owner in a poorer district of İstanbul, explicitly evokes the idea of false history:

In my opinion, it is wrong to have television series like this. If you are going to tell history, to do good things, yes, then let them do it. But if they are

48 For a broader discussion on arabesk, see Martin Stokes, The Arabesk Debate: Music and Musicians in Modern Turkey (Oxford: Oxford University Press, 1992). 
going to depict love stories, intrigues among women, etc., then it's wrong.

I believe they are deceiving people, they are depicting everything falsely.

As someone who claims to have never set foot in a mosque, Murat is a good example of how concerns about a "proper" Ottoman history are not only limited to a particular form of religiosity. For respondents in this group, stories of everyday life in the imperial palace that are disconnected from great historical events like wars do not count as proper history: they can only be false depictions to deceive people. İbrahim (Respondent 23), a civil servant in Kayseri, disapproves of The Magnificent Century because it does not depict the life of Sultan Süleyman correctly: "They made a monkey out of a sultan like Süleyman the Magnificent. How can I watch it?" He goes on to say that Süleyman spent almost his entire life on horseback and would not have had the time to take part in palace intrigues. He also adds, "I heard somewhere that the script writers do this to increase ratings. However, the Ottoman Empire is not only about Sultan Süleyman. It changed from sultan to sultan like how our country changes from prime minister to prime minister." In İbrahim's statement, we see a disbelief in the notion that Sultan Süleyman would take part in palace intrigues, but with the respondent also identifying the complexity of the Ottoman past by acknowledging how every sultan's reign must have been different, similar to the way contemporary politics change.

A second group of consumers pairs their criticisms of bad history with arguments relating to guilty pleasures. These respondents couple reports of their own enjoyment of Ottomania with claims that these very products of popular culture are harmful for others. Even staunch critics of popular representations of Ottoman history are quick to point out that historical truth would not sell. One common refrain, reminiscent of the pleasure-centered defense of popular culture, was that television series are not documentaries. Barbaros (Respondent 9), a practicing Muslim and supporter of the ruling AKP, refuses to expose his children to The Magnificent Century, while simultaneously acknowledging the show's allure. His concern relates primarily to others' misinterpretations: "They are not making a documentary here. I mean, this is fiction. I am critical of this because some people confuse it with reality." If sultans were depicted as moral individuals and if television dramas emphasized Islamic conservatism, he adds, "of course nobody would watch them."

Audiences in Turkey enjoy Ottomania with their cultural shields up. Combining a social view of historical degeneration with an individual view of pleasure, consumers of Ottomania absolve their immersion in popular culture, believing that their critical stance makes them impervious to intrusions of the so-called "false history." For them, it is others who are not as aware who are at risk. As explained by the third-person effect hypothesis, "people tend to 
overestimate the influence that mass communications have on the attitudes and behavior of others." ${ }^{\prime 9}$ In line with this, Barbaros was briefly flustered when he tried to combine arguments about individual pleasure and social harm:

Interviewer: You said you watch The Magnificent Century. Do you like it? Respondent: No!

Interviewer: Do you mean you watch it even though you don't like it? Respondent: I know it's an absurd answer, but technically it's a very good television series. When you look at it as a film, when you look at the costumes and the continuity of the script, it's truly a solid series. And it attracts a lot of attention... But obviously I have serious objections to its script [content]. We call it fiction, but it's not that simple. When you depict a character in it, that's how that character remains in people's eyes.

It is not paradoxical that The Magnificent Century was possibly the most popular and the most disdained television series at one and the same time. Similarly, during its heyday, arabesk's assault on "good" Western music marked similar strategies to distinguish between "the music I like" and "good music." The gradual withdrawal of debates around the proper modernity of cultural forms reframed the contemporary cultural field: the tension now is between "the history I like," which refers to popular depictions of history for pleasure, and "proper history," a discourse of historical "truth" that many feel is under attack by a pleasure-oriented popular culture. Perceptions of "proper" history shape the ways in which individuals negotiate the tensions between the pleasures of popular culture and their own sense of what correct history is or should be. From these negotiations, a number of positions and perceptions emerge regarding the Ottoman past.

\section{The different faces of the Ottoman past}

Individuals' reception of popular cultural products undergoes decoding and interpretation. ${ }^{50}$ The reception of Ottoman history is no less complex and contextually bound. Our interviews show that there is neither a single, coherent Ottomania, nor do perceptions of popular history match dichotomous axes such as religious versus secular. The complex position of Ottomania renders a picture in which individuals and collectivities fashion and consume the past in

49 W. Phillips Davison, "The Third-Person Effect in Communication," Public Opinion Quarterly 47, no. 1 (1983): 1-15.

50 See, e.g., Sonia M. Livingstone, Making Sense of Television: The Psychology of Audience Interpretation (London and New York: Routledge, 1998) and David Morley and Charlotte Brunsdon, The Nationwide Television Studies (London and New York: Routledge, 1999). 
ways that transgress clear-cut distinctions. On the one hand, Islamism in Turkey gets absorbed into capitalism ${ }^{51}$ as Muslims integrate into a commercialized and pleasure-oriented popular culture. On the other hand, people who identify as secular demonstrate concerns with the depictions and reinterpretations of the Ottoman past. In this emergent picture, individuals can and do shift positions even within the course of the same interview. Given the in-depth nature of our data, we hereby present the structures of argumentation within the four discursive frames presented below.

"We can't even solve the Kurdish issue": Ottomans as the epitome of tolerance

Proponents of this view, which is an explicitly state-supported narrative, see the Ottoman Empire as a tolerant multicultural empire and as evidence for this tolerant heritage they offer oft-cited events, such as the Ottomans providing safe haven to Sephardic Jews escaping from the Spanish Inquisition. ${ }^{52}$ This is a picture of a "golden age" in which different religious and ethnic groups lived together peacefully, a picture which has been criticized by Barkey, BrinkDanan, and Iğsiz. ${ }^{53}$ Hatice (Respondent 4), a female college student who identified herself as religious, contrasted the idea of a tolerant Ottoman Empire with the republican and nationalist history presented in textbooks, which painted the late Ottoman period as one of decline. Her image of Turkey's "golden age" gives the country an international leadership role:

[W]e are trying to revive the Ottoman Empire today. We all grew up reading [...] books that taught us how bad the Ottoman Empire was, and how it declined and died and we successfully established a new state [...] Who was there in the Ottoman Empire? Russians, Macedonians, Armenians, Arabs. They all accepted the same boundaries, and they all respected the sultan's rule and found peace in his reign, securing themselves from other countries. Nowadays, when Turkey goes to another country for military reasons or to give aid or help after an earthquake, it looks as if people there are welcoming Turks. You see Turkish flags everywhere [...] There is always an expectation that they still have the taste of Ottoman rule, the rule of our ancestors, in their memory and want to have some more of it. But Turkey is not there yet, to take that responsibility, because it is itself at war. Turkey has one single

51 Cihan Tuğal, Passive Revolution: Absorbing the Islamic Challenge to Capitalism (Stanford: Stanford University Press, 2009).

52 Murat Ergin, "Cultural Encounters in the Social Sciences and Humanities: Western Émigré Scholars in Turkey," History of the Human Sciences 22, no. 1 (2009): 105-130.

53 Brink-Danan, "Dangerous Cosmopolitanism"; Barkey, "Rethinking Ottoman Management of Diversity"; Iğsız, "Palimpsests of Multiculturalism and Museumization." 
ethnic problem [referring to the Kurdish issue], and it is not even able to solve that one problem, and it is expected to have a say in the Arab issue? Turkey does not have that much power. All it has is charisma.

The state-sponsored neoimperial model in Hatice's mind-i.e., the good "taste of Ottoman rule" and people in other countries welcoming Turks-clashes with Turkey's current ethnic problems. Thus, even while criticizing previous nationalist narratives of Ottoman decline, respondents struggle to reconcile the Ottoman "golden age" with contemporary problems. Hatice recognizes how the picture of a multicultural Ottoman past and the depiction of Turkey's reception in other countries do not fit the realities of current ethnic troubles. She uses an imaginary coexistence in the past to problematize contemporary ethnic relations. We find the same comparison of past glories with contemporary problems in the words of Hafsa (Respondent 18), a young teacher from İzmir who identified herself as a liberal and moderately religious person:

What comes to my mind when I say Ottoman is this: how did the Ottomans manage to keep so many peoples together? We cannot even manage to sit side by side as two individuals [today] [...] So many groups from different ethnicities managed to live together. How was that accomplished and why can't we do it [today]?

Employing the comparative framework of a glorious past vis-à-vis a trouble-ridden present, even those who question the current government's motives for promoting a narrative of tolerance still harbor a sense of yearning for a romanticized Ottoman coexistence. Many feel that Ottoman rule simply must have offered peace and prosperity to diverse groups. Respondents expressed the comparative tolerance of the Ottomans in both ethnic and religious terms. Hafsa, for instance, placed a multicultural Ottoman entity in direct contrast with an ethnically troubled contemporary Turkey: "We can't even solve the Kurdish issue. How did so many people live peacefully in the Ottoman Empire?" Ayşe (Respondent 17), from İzmir, commented on Ottoman religious tolerance, but with the explicit goal of criticizing what she saw as contemporary Turkey's inability to manage religious fundamentalism. For her, a tolerant Ottoman religiosity becomes a yardstick by which to measure and evaluate current troubles. Thus, her statements about Ottoman religious tolerance are intended to criticize the current government just as much as they are to describe the past:

Today, in this country where 98 or 99 percent are Muslims, religion is dominant and even religious massacres are possible, which do happen. For example, you know Mardin [a city in southeastern Turkey]. In Mardin, 
for example, a number of religions exist and people live there comfortably. Barring interference from the outside, those people have been living together for a long time. They did [this] in the Ottoman period [as well]. I don't know this very well, but I think there were periods [in the Ottoman past] when religion was not so dominant.

While Ayşe's attention to the loss of religious diversity is a challenge to contemporary homogeneity, some of the more religious respondents viewed Ottoman tolerance as evidence for Islam's superiority. For Selim (Respondent 10), a college student from an Anatolian town and a practicing Muslim, an understanding of Ottoman tolerance can help against misconceptions regarding Islam. Thus, he offers the pax Ottomanica as a global model: "We always say it: in former Ottoman territories, the bloodshed never stops [because the Ottoman-ensured peace in those regions ended] [... ] So, we don't really understand the Ottomans. If we did, we wouldn't be debating the Kurdish issue or education in one's mother tongue." Ayşe and Selim's statements highlight how similar discursive strategies can be used to different ends, in accordance with an individual's background.

\section{"Our roots Are Ottoman": Ottomans as the Turks' ancestors}

The Turkish ethnic identity of the Ottomans is widely accepted in contemporary Turkey. Respondents employed an imagery of Turkey's Ottoman roots to establish an uninterrupted link between the past and the present. Our interviews indicate that the growing interest in the Ottoman past has helped popularize and solidify the view of the Ottomans as the ancestors of contemporary Turks. This is a view that stands in tension with the previous interpretive cluster of Ottoman multiculturalism. For several individuals, the way out of the resulting impasse is to revert to a language of descent, one that is seemingly less problematic than outright ethnic claims. However, this gesture depends on the implicit assumption that non-Turkish groups were guests tolerated by the empire's true owners. Mahmut (Respondent 12), a high school graduate who runs a small shop in İstanbul, relies on an effortless transition from the Ottoman to the Turkish, a transition which does not necessitate elaboration for him:

The meaning of the Ottomans for Turkey is great. Because if it weren't for the Ottoman Empire, we would not be able to live comfortably on our soil, we would not have this society anyway. In my opinion, we owe everything, our entire territory, to the Ottoman Empire.

Similarly, Gülbahar (Respondent 21), a high school graduate and homemaker from Kayseri, replied to our question on the meaning of the Ottomans for 
Turkey by emphasizing a continuous lineage: "It's our roots. Our lineage comes from the Ottomans without interruption. It's not something that comes from the outside."

The necessity of teaching Ottoman history occupies a prominent place in the narratives of continuity between the Ottoman past and the Turkish present. For Nur (Respondent 1), a college student who identified herself as moderately pious, "not only every Turkish young person, but also every Turkish citizen should know [his/her] own race, history, everything." For these respondents, popular cultural representations represent a degeneration of the Ottomans' heroic history. Teaching and learning "true" history is considered the panacea for correcting misconceptions, as revealed in the words of Mahmut:

If I were married and had a child, I would first need to inculcate in him/her [his/her] history, [his/her] past, so that [he/she] could be faster and more efficient in making life choices. When one reads about or watches what happened in the past, one trembles and feels pride about them [...] Words are not enough to tell such things. I feel pride about what the Ottomans did.

Respondents who identify as secular also took the ethnic connections between the Ottomans and contemporary Turkey as fact, although they were more cautious in celebrating Ottoman achievements. Osman (Respondent 6), a shopkeeper in İstanbul, said:

Before Turkey there was the Ottoman Empire. It collapsed and the Republic of Turkey was established. Secularism was established. A new country, a new system [...] But of course we are related, affiliated, we have a connection. They are our roots, our pedigree. It would be bizarre to say we are not affiliated, but we should not go to extremes in this.

The dilemma for self-proclaimed secular people arises from the need to deal with the increasingly popular representation of the Ottomans as defenders of Islam. For them, recognizing continuities necessitates efforts to subdue Ottoman Islam. As Osman's words indicate, this is a matter of setting limits and not going to "extremes." Murat expresses a similar caution about separating ethnic links from religious continuity: "The Ottomans and contemporary Turkey should not have any relationship. Okay, perhaps we come from that lineage, but Turkey and the Ottomans are completely different [... Today, we don't have anything to borrow from the Ottomans, or any resemblance to them." 
"The Ottoman Empire was the sword of Islam against the West": Ottomans as defenders of the faith

For respondents in this interpretive cluster, the Ottomans and Islam cannot be envisioned independently of one another. Selim expressed this view as follows: "I don't consider the Ottomans separate from Islam. The Ottomans were the bearers and promoters of Islam. Against the West, they were the swords and standard bearers of Islam." Embraced by respondents with a more conservative bent, this position constructs a timeless and ambiguous Islamic golden age in the Ottoman past. When asked about what the Ottomans mean to him, Barbaros explicitly evaluated Islamic and Turkish identities, ultimately opting for the former:

If I had to respond briefly, I would say it means the last Islamic state and the last Islamic empire for me. As a person who moves around the axis of Islamic identity rather than [that of] Turkishness, we can call it the last Islamic empire or the last Islamic state [... ] [Turkey] is the last geography left from the Ottoman Empire where a Muslim society lives. Of course, not in the sense of today's administrative structure and values [critically referring to Turkey's secularism], but it should be acknowledged that Turkey carries the Ottoman legacy [...] The Ottoman Empire was established by Turks, and our name today is Turkey and racially we are Turks, but that part does not mean anything to me.

As in previous interpretive clusters, respondents who associate the Ottomans with Islam intend their remarks about the past to be an evaluation of contemporary conditions. They use their conceptions of history to make sense of and remark on the present. In particular, those who identify as practicing Muslims direct their criticism against a perceived moral degeneration in contemporary Turkey. In this sense, remarks about representations and misrepresentations of "proper" history occupy an especially important place. The most frequently voiced target of moral condemnation has to do with representations of Ottoman sexuality in popular culture. The Magnificent Century attracts a disproportionate amount of attention in critiques based on morality, with debates in the media placing abundant emphasis on depictions of Sultan Süleyman's sexual life on television. In addition, our respondents seemed to be concerned more with the low-cut and revealing costumes of the women acting in period dramas. Gülfem (Respondent 3), a high school graduate and homemaker from İstanbul, framed sexuality in terms of women while giving the task of controlling female sexuality to the sultan: "Let's think about those times. The sultans are really pious individuals. They wouldn't let their wives be seen in the palace by strangers. But [in The Magnificent Century] Hürrem appears to others as if she just got out of bed. This shouldn't be so [..+] This sexuality, these 
low-cut and revealing outfits, these are too extreme." Similar to Gülfem, Nigar (Respondent 22), a college-educated homemaker in Kayseri who votes for parties representing the Islamist National Vision (Millî Görüş) position, questioned the historical accuracy and moral appropriateness of the costumes the women of the palace wear in the show: "First of all, these outfits are too revealing. I don't know if they could be dressed in this way in a country where Sharia was in effect." By articulating their concerns about the depiction of the Ottoman palace women, our respondents are not only talking about history, but also signaling where they stand with regard to gender roles, women's sexuality, and moral boundaries.

"Turkey suffers from the mistakes committed by the Ottoman Empire": The Ottomans as burden

The views outlined above-which glorify the Ottomans as tolerant, Turkish, and Islamic - do have their detractors, who consider the Ottomans responsible for contemporary problems. Aware of the popularity of those outlooks that glorify the Ottomans, these respondents specifically target the Ottomans' tolerance, Turkishness, and Islamic piety. Such a distance from the Ottoman past is generally sustained by avowedly secular positions. Ayşe, for example, believes that the famed tolerance of Ottoman Empire is an illusion propagated by the current government. Mehmet (Respondent 14) criticizes the view that the Ottomans were Turks. A college graduate who identified as non-religious and leftist, he explicitly distinguishes the Turks from the Ottoman dynasty:

People think that they come from the Ottomans, or that they are descendants of the Ottoman pedigree, but in reality we did not come from the Ottomans. We are a people who have been living in Anatolia. The Ottomans, however, are a family [...] They ruled over all the people who lived in these territories. Because our people are very much attached to their pasts, and because the Ottomans are not related or taught to them properly, and because they don't know much about the Ottomans, our people, I think, are proud of the Ottomans. But in reality they don't know about the Ottoman Empire or that system. If they knew the structure or the system [of the Ottomans] in its reality, they would not think that way.

Mehmet's view resonates with the early republican narrative insofar as it distinguishes between Turkish and imperial identities. He contends that if only people were properly educated, they would stop being proud of the Ottomans and recognize them for the dynastic rulers that they were. İbrahim (Respondent 13), a university graduate who identified as a practicing Muslim, draws a picture of uninterrupted sin independent of historical periods, something to which the 
Ottoman people were not immune. His view that the Islamic nature of the Ottoman Empire was an illusion is connected with this particular reading of human nature, rather than with a critique of Islamism:

Nowadays when you say the Ottomans, people have the perception that true religion was practiced properly only then but not now, but I don't think this is true. The only thing that has changed between then and now is the fact that people used to do a lot of things in secret then, and now they can do them openly. People did not change. Their thoughts, what's inside them are the same. People never change. It's just that what was previously hidden comes out in the open.

In line with the previous interpretive clusters, those respondents who see the Ottomans as a burden linked this position to contemporary problems. Some, like Nur, cited atrocities committed by the Ottomans and their perception in the West as reasons for restraint, if not shame, regarding the Ottoman past:

For Turkey, the Ottoman Empire is a burden. Because it ruled over such a vast geography and could make its voice heard all over the world in the past, but now Turkey cannot even enter the EU. Turkey today is repressed, in fact. I believe Turkey suffers from the mistakes committed by the Ottoman Empire. The Ottomans hurt so many [...] Greece, Iraq, France, England. Turkey is disliked in a lot of countries.

Nur's comments frame Turkey's inability to join the European Union as an issue linked to the Ottomans, rather than as a problem with European perceptions and attitudes, as is commonly done in Turkey. The discourse about the mistakes committed by the Ottomans was also voiced by some respondents who had had interactions with foreigners. One example of this comes from Mehmet, who narrates his encounter with a Hungarian woman at his workplace:

I think she was also interested in history. She said, "The governor that your sultan sent to us died in his nineties and he went to bed only with virgins until his death." When she said that, we of course were unable to respond $[\ldots]$ A person who goes through this would of course hate you, no matter how many years have passed. Because people in our country never face these facts, because they are never told such things, because talking about these things is taboo. I don't think people know the Ottomans, that system [...] If someone says that the Ottomans were good, I would suspect that person's 
knowledge or humanity. I don't think we can explain these things away by saying "the times then required it."

Mehmet's story of collective memory provides, to him, evidence for a problematic Ottoman past glorified by a "false" history. He makes sense of the Ottoman past through an encounter with the other. Although earlier in his interview he had said that he does not identify with the Ottoman Empire because "we" are a people from Anatolia, here his "we" shifts when he interacts with a person from Hungary as not only a person from Turkey, but also a descendant of the Ottoman Empire.

\section{Conclusion}

Our interviews show how the state's vision of neo-Ottomanism is at times challenged through a questioning of the discourse of tolerance that the state promotes, as well as through a disbelief in the feasibility of bringing the pax Ottomanica into a region where "we can't even solve the Kurdish issue." Moreover, where one sees a tolerant past, another sees an occupying force, something to be ashamed of in the course of an encounter with a foreigner. One way or another, thinking about the Ottoman past in the context of neo-Ottomanism and Ottomania is a way of offering social commentary on the present: our respondents articulated what they think contemporary Turkey should look like and what subjectivities should be central to current selfperceptions. The mismatches of perception between The Magnificent Century's producers, conservative state officials, and religious groups, which led to gradual self-censorship by the show's script writers, indicate that Ottomania is a contentious domain molded not only by the producers but also by public responses. Neo-Ottomanism, a more conscious and intentional identity project, also defines itself in relation to Ottomania and to debates around "proper" history, feeding on its arguments in order to define what it is and what it is not. The "proper history" narrative shifts from person to person and from institution to institution, thereby weaving state and popular discourses together. Popular culture's perceived degraded position makes it easier to deem historical drama "false history," thus providing a platform that allows one to signal one's political, religious, racial, and gendered position to the other.

"Authentic" or "proper" history gets reproduced by engagement with the television series through respondents' previous exposure to Ottoman history via already mediated sources, such as a nationalist state curriculum ${ }^{54}$ that teaches a linear Ottoman past. The idea of a "false" history becomes even more plausible

54 See Çınar, Collective Memory and National Membership. 
for those viewers who have also already embraced the vision that popular culture disseminates a degraded version of reality. In other words, The Magnificent Century becomes a fictional point of reference in terms of what history must not have looked like, in this way opening the ground for discussion of the non-fictional Ottoman Empire and shedding light on current nationalistic, religious, and gendered inclinations in Turkish society. Taking a cue from The Magnificent Century — which, according to them, is too occupied with palace intrigues-respondents paint an alternative Ottoman past using tools from the nationalist school curriculum, the AKP's discourse of a multicultural and just Ottoman Empire, and other public sources. As painted by our twenty-five respondents, this collective picture is complex in its details. However, its central narrative reveals an Ottoman Empire that was tolerant within its borders while also operating as an Islamic imperial force, which Turkey, as its heir, should be either proud or ashamed of, depending on the informant's identity.

\section{References}

Ahıska, Meltem. "Occidentalism and Registers of Truth: The Politics of Archives in Turkey." New Perspectives on Turkey 34 (2006): 9-28.

Ahıska, Meltem and Biray Kolluoğlu Kırlı. "Editors' Introduction." New Perspectives on Turkey 34 (2006): $5-8$.

Aytürk, Ilker. 2004 Turkish Linguists against the West: The Origins of Linguistic Nationalism in Atatürk's Turkey." Middle Eastern Studies 40 (6): 1-25.

Baer, Alejandro. "Consuming History and Memory through Mass Media Products." European Journal of Cultural Studies 4, no. 4 (2001): 491-501.

Barkey, Karen. "Rethinking Ottoman Management of Diversity: What Can We Learn for Modern Turkey?" In Democracy, Islam and Secularism in Turkey. Edited by Ahmet Kuru and Alfred Stepan. New York: Columbia University Press, 2010. 12-31.

Bartu, Ayfer. "Rethinking Heritage Politics in a Global Context: A View from İstanbul." In Hybrid Urbanism: On the Identity Discourse and the Built Environment. Edited by Nezar AlSayyad. Westport, CN: Praeger Publishers, 2001. 131-155.

Bezmez, Dikmen. "The Politics of Urban Regeneration: The Case of the Fener and Balat Initiative." New Perspectives on Turkey 37 (2007): 59-86.

Bourdieu, Pierre. Distinction: A Social Critique of the Judgment of Taste. Translated by Richard Nice. Cambridge, MA: Harvard University Press, 1984.

Brink-Danan, Marcy. "Dangerous Cosmopolitanism: Erasing Difference in İstanbul." Anthropological Quarterly 84, no. 2 (2011): 439-473.

—. Jewish Life in Twenty-First-Century Turkey: The Other Side of Tolerance. Bloomington: Indiana University Press, 2011.

Candan, Ayfer Bartu, and Biray Kolluoğlu. "Emerging Spaces of Neoliberalism: A Gated Town and a Public Housing Project in İstanbul." New Perspectives on Turkey 39 (2008): 5-46.

Çınar, Alev. Modernity, Islam, and Secularism in Turkey: Bodies, Places, and Time. Minneapolis: University of Minnesota Press, 2005.

Çınar, Meral Uğur. Collective Memory and National Membership: Identity and Citizenship Models in Turkey and Austria. London: Palgrave Macmillan, 2015.

Davison, W. Phillips. "The Third-Person Effect in Communication." Public Opinion Quarterly 47, no. 1 (1983): 1-15.

Davutoğlu, Ahmet. Stratejik Derinlik: Türkiye'nin Uluslararası Konumu. İstanbul: Küre Yayınları, 2001. 
Ergin, Murat. "On Humans, Fish, and Mermaids: The Republican Taxonomy of Tastes and Arabesk." New Perspectives on Turkey 33 (2005): 63-92.

. "Cultural Encounters in the Social Sciences and Humanities: Western Émigré Scholars in Turkey." History of the Human Sciences 22, no. 1 (2009): 105-130.

- Is the Turk a White Man? Race and Modernity in the Making of Turkish Identity. Leiden and Boston: Brill, 2016.

Ersanlı, Büşra. "The Ottoman Empire in the Historiography of the Kemalist Era: A Theory of Fatal Decline." In The Ottomans and the Balkans: A Discussion of Historiography. Edited by Fikret Adanır and Suraiya Faroqhi. Leiden: Brill, 2002. 115-154.

Fisher Onar, Nora. "Constructing Turkey Inc.: The Discursive Anatomy of a Domestic and Foreign Policy Agenda." Journal of Contemporary European Studies 19, no. 4 (2011): 463-473.

Fiske, John and John Hartley. Reading Television. London and New York: Routledge, 2003.

Frith, Simon. "The Good, the Bad, and the Indifferent: Defending Popular Culture from the Populists." Diacritics 21, no. 4 (1991): 106-107.

Hall, Stuart. "Encoding/Decoding." In Culture, Media, Language: Working Papers in Cultural Studies, 1972-79. Edited by Stuart Hall, Dorothy Hobson, Andrew Lowe, and Paul Willis. London: Routledge, 2005 (1980). 117-127.

Iğsız, Aslı. "Palimpsests of Multiculturalism and Museumization of Culture: Greco-Turkish Population Exchange Museum as an Istanbul 2010 European Capital of Culture Project." Comparative Studies of South Asia, Africa and the Middle East 35, no. 2 (2015): 324-345.

Kirişçi, Kemal and Neslihan Kaptanoğlu. "The Politics of Trade and Turkish Foreign Policy." Middle Eastern Studies 47, no. 5 (2011): 705-724.

Kraidy, Marwan M. and Omar Al-Ghazzi. "Neo-Ottoman Cool: Turkish Popular Culture in the Arab Public Sphere." Popular Communication 11, no. 1 (2013): 17-29.

Kuyucu, Tuna and Özlem Ünsal. "'Urban Transformation' as State-Led Property Transfer: An Analysis of Two Cases of Urban Renewal in İstanbul." Urban Studies 47, no. 7 (2010): 1479-1499.

Livingstone, Sonia M. Making Sense of Television: The Psychology of Audience Interpretation. London and New York: Routledge, 1998.

Mills, Amy. Streets of Memory: Landscape, Tolerance, and National Identity in Istanbul. Athens: University of Georgia Press, 2010.

. "The Ottoman Legacy: Urban Geographies, National Imaginaries, and Global Discourses of Tolerance." Comparative Studies of South Asia, Africa and the Middle East 31, no. 1 (2011): 183-195.

Morley, David and Charlotte Brunsdon. The Nationwide Television Studies. London and New York: Routledge, 1999.

Murinson, Alexander. "The Strategic Depth Doctrine of Turkish Foreign Policy." Middle Eastern Studies 42, no. 6 (2006): 945-964.

Öncü, Ayşe. "Representing and Consuming 'the East' in Cultural Markets." New Perspectives on Turkey 45 (2011): 49-73.

Özyürek, Esra. Nostalgia for the Modern: State Secularism and Everyday Politics in Turkey. Durham: Duke University Press, 2006.

The Politics of Public Memory in Turkey. Syracuse: Syracuse University Press, 2007.

Peterson, Richard A. and Albert Simkus. "How Musical Tastes Mark Occupational Status Groups." In Cultivating Differences: Symbolic Boundaries and the Making of Inequality. Edited by Michèle Lamont and Marcel Fournier. Chicago: University of Chicago Press, 1992. 152-168.

Peterson, Richard A. and Roger M. Kern. "Changing Highbrow Taste: From Snob to Omnivore." American Sociological Review 61, no. 5 (1996): 900-907.

Potuoğlu-Cook, Öykü. "Beyond the Glitter: Belly Dance and Neoliberal Gentrification in İstanbul." Cultural Anthropology 21, no. 4 (2006): 633-660.

Quataert, Donald. The Ottoman Empire, 1700-1922. Cambridge and New York: Cambridge University Press, 2008.

Rankin, Bruce H., Murat Ergin, and Fatoş Gökşen. "A Cultural Map of Turkey." Cultural Sociology 8, no. 2 (2014): 159-179. 
Sakaoğlu, Necdet, and Ayşen Gür. "Muhteşem Yüzyılın Anatomisi: Sultan Süleyman Dönemi Dünya $\mathbf{z}$ Sistemi." NTV Tarih 25 (2011): 26-39.

Sirman, Nükhet. "Constituting Public Emotions Through Memory: Interviewing Witnesses." New Perspectives in Turkey 34 (2006): 31-46.

Stokes, Martin. The Arabesk Debate: Music and Musicians in Modern Turkey. Oxford: Oxford University Press, 1992.

Tuğal, Cihan. Passive Revolution: Absorbing the Islamic Challenge to Capitalism. Stanford: Stanford University Press, 2009.

White, Jenny. Muslim Nationalism and the New Turks. Princeton, NJ: Princeton University Press, 2014.

Williams, Raymond. Television: Technology and Cultural Form. London and New York: Routledge, 2003. 